\title{
Andreas Fickers \\ The Emergence of Television as a Conservative Media Revolution: Historicising a Process of Remediation in the Post-war Western European Mass Media Ensemble
}

The emergence of television in post-war Europe was a long and asynchronous process. Despite the many faces that the new medium adopted according to the different political and cultural environments in which it was embedded, the contemporaries commonly celebrated the advent of television as a revolutionary moment in the history of communication. The new «window to the world» or «fifth wall» ${ }^{1}$ was said to have the magic potential of transmuting the living room into an electronic space of exploration for millions of «armchair discoverers».

This article revisits some of the popular narratives about the emergence of television as a revolutionary moment in European mass media history by highlighting the struggles that the new medium encountered in the search for its medial identity. It focuses on a set of negotiations where the tensions between the conservative and modernising agencies of the medium became most visible or explicit. These sites reflect the three dimensions of the televisual dispositif: the technological or infrastructural «hardware», the institutional structure and the socio-cultural meaning of television as negotiated in early television discourse. ${ }^{2}$ The article explores the battles over the construction of a medial identity of television, and the diverging ambitions to establish national television infrastructures to promote national communion. It touches upon a number of interrelated questions: First, was television more an agent of national socialisation or of transnational imagination? Second, how do we qualify the «newness» of television as a medium entering the Western European mass media ensemble? Third, did the cultural and political function of television foster a «conservative media revolution» in post-war Western Europe? Can the emergence and establishment of television as a mass medium in

1 W. Rings, Die 5. Wand: Das Fernsehen, Wien, I962.

2 The concept of dispositif as developed by the French film theorist Jean-Louis Baudry characterises the specificity of a medium - in Baudry's case of the cinema - as the result of interrelation between three factors: technology (called «appareil de base»), content (the filmic text) and perception (the viewing). All three factors together create the «illusion of reality» as an intrinsic quality of the film as medium. See Frank Kessler, Notes on dispositif, online manuscript:_http://www.let.uu. nl/ frank.kessler/personal/Dispositif\%20Notes112007.pdf. 
most European countries during the I950 and I960 really be classified as a revolutionary moment in media history?3

To answer these questions, I propose analysing the advent of television as a new technology and emerging medium in an integrative media historical perspective by reflecting on the technological and infrastructural foundations of the European television landscape and investigating the political contexts that shaped the institutionalisation of the medium. Last but not least, the intermedial relationships and interdependencies between television and other mass media have to be taken into account, as they framed the invention of television as a new medium.

With some exceptions, the historiography of modern mass media has been - up until now - dominated by two research perspectives: by the nation as primary frame of historical investigation and by a focus on single medium narratives. In addition, general histories tend to be fixated on the period of arrival of a «new» medium, overlooking the continuous existence and importance of the apparently «old» media. Although a number of authors have alluded to the pitfalls of this binary logic of «old» versus «new», and «pre-» versus «remediation» ${ }^{4}$, the temptation to reconstruct the history of media in a linear historical narrative of succession or even substitution of different media still seems to be strong. While national histories of single media are undoubtedly legitimate in the context of the formation of national identity or political cultures and social movements, they are of limited use when trying to understand the role of mass media in the process of cultural modernisation and globalisation. This article claims that only a comparative and transnational perspective can elucidate the national specificities and transnational communalities of media as agents of cultural transfer and mediators or catalysts of social or political debates. ${ }^{5}$ In addition, contemporary media historiography lacks an intermedial perspective that sheds light on the complex interrelationships between both the different media in the mass media ensemble and their synchronous agency in modern history. Only such an intermedial perspective will pave the way for an integrative media historiography ${ }^{6}$ that analyses the complex processes of mutual reinforcement of different media, and critically historicises the continu-

3 This article builds on extensive literature and archival research that was gathered in the framework of a VENI project, funded by the Netherlands Organisation for Scientific Research (NWO). The project concentrated on a comparative historical analysis of the emergence of television in Great Britain, Germany, the Netherlands and France.

4 G. B. Pingree / L. Gitelman, «What's new about new media?», in: L. Gitelman / G. B. Pingree (eds.), New Media 1740-1915, Cambridge/Mass. 2003; W. Chun (ed.), New Media, Old Media. A History and Theory Reader, London 2006. The concept of remediation as developed by Bolter and
Grusin argues that new visual media achieve their cultural significance by paying homage to, rivalling, and refashioning earlier media such as perspective painting, photography, film, and television. See J. Bolter / R. Grusin, Remediation. Understanding New Media, Cambridge/Mass. 2000.

5 J. Bignell / A. Fickers (eds.), A European Television History, Malden 2008; A. Fickers / C. Johnson, «Transnational television history: a comparative approach. Introduction», in: Media History I6 (2OIO) I, I-II.

6 For a theoretical reflection on the concept of intermediality and its consequences for an integral me- 
ous reinvention and remediation of all media (and not only the «new» medium) in moments of transition or change in the mass media ensemble. ${ }^{7}$

While most of the recent studies looking at processes of remediation focus on the incorporation and appropriation of existing media products and practises into the new digital media following a logic of convergence, ${ }^{8}$ it is important to emphasise that these processes always involve mutual interference and transfer. The rise of television not only changed the fragile balance in the hitherto existing mass media ensemble but forced all mediums to reposition themselves and to react to the «threat» of the newcomer. The invention, development and implementation of a new communication technology and medium is by definition a phase of uncertainty, of negotiation and of creative exploration. ${ }^{9}$ Steve Wurlitzer has explored the intermedial relationships of interrelated sound technologies of the I920s and I930s (the sound cinema, the phonograph and the radio). He highlights the complex and hybrid relationships between technologies as object, practise and discourse: «Upon their innovation, media technologies have multiple, often conflicting identities. The ultimate meanings they take within social relations are the product of contestation and struggle. Various mechanisms - some economic or regulatory, others ideological or material - function to privilege one set of meanings over others as media technology is successfully secured within social habits and practices». ${ }^{10}$ Instead of emphasising the «revolutionary» character of this process, Wurlitzer shows that the grafting of electrical sound technology onto the existing institutions and practises of cinema and phonograph was «conservative», in an economic, aesthetic and technological sense. The material and rhetorical struggles to shape the identity of radio as a new medium led to a process of reconsolidation within the existing media landscape - «institutional realignments related to technological change exacerbated ongoing consolidation within each industry» and forged the re-articulation of previously established positions on cultural and political life. ${ }^{11}$

In a similar vein, this article intends to demonstrate that the emergence of television must be interpreted as a conservative media revolution. What is meant by this term? It expresses in a short but punchy way the ambivalent status of an emerg-

dia historiography, see J. Müller, «Intermedialität und Medienhistoriographie», in: J. Paech / J. Schröter (eds.), Intermedialität - Analog / Digital. Theorien, Methoden, Analysen, München 2008, $3 \mathrm{I}-46$.

7 S. Holmes, «A friendly style of presentation which the BBC had always found elusives. The I950 cinema programme and the construction of British television history», in: H. Wheatley (ed.), Re-Viewing Television History. Critical Issues in Television Historiography, London 2007, 70.

8 H. Jenkins, Convergence Culture. Where Old and New Media Collide, New York 2006.
9 B. Winston, Media, Technology and Society. A History: From the Telegraph to the Internet, London I998.

10 S. Wurlitzer, Electric Sounds. Technological Change and the Rise of Corporate Mass Media, New York 2007, I5; W. Uricchio, «Historicizing Media in Transition», in: D. Thorburn / H. Jenkins (eds.), Rethinking Media Change. The Aesthetics of Transition, Cambridge 2004, 23-38.

11 Wurlitzer, Electric Sounds, 69. 
ing medium that was accompanied by a revolutionary rhetoric but in fact developing in a framework of conservative patterns. I want to pay particular attention to the conservative nature of television as a new technology, institution, and cultural form. The term «conservative» is used here in two different ways: First, it is used in a theoretical sense, highlighting the fact that television cannot be described as a «radical innovation», but must instead be interpreted as a «conservative innovation». According to the concept of «conservative innovation», most technical innovations improve or complement existing technologies and rarely offer radically new solutions. ${ }^{12}$ My argument builds on this idea and expands it to the institutional, aesthetic and cultural dimension of television.

Second, the term «conservative» is used in a normative sense. During the phase of reconstructive modernism, ${ }^{13}$ television gradually took over the role of new leading medium in the mass media ensemble. In this process of reconfiguration of the mass media ensemble, television distinguished itself as the legitimate successor of radio, which was previously the central actor of national community building. Focussing on the nation, the family and the home, television - at least in Western Europe and the United States - became both an object and vehicle for the (re)production and dissemination of a conservative post-war ideology. To paraphrase the provocative thesis of Alan Milward, one could label television as the «moral rescue of the nation state». ${ }^{14}$ These patterns of conservative ideology are visible in the technological design of post-war television infrastructures, in the organisational profiles of television institutions and in the cultural products of television programmes.

In the first part of this article, I will describe television's emergence as a conservative media revolution, following an intermedial approach. The second part will investigate television's relationship to national and transnational spaces, both in a physical and mental sense.

\section{The Development of Television as a Conservative Innovation}

Following Thomas P. Hughes> concept, the invention of television must be qualified as a conservative innovation. The wireless transmission of moving pictures was an addition or complement to the radio rather than a radical transformation or technological alternative to it. While the transition from wired telegraphy to wireless broadcasting manifests the technological (not the institutional or economic) characteristics of a radical innovation, ${ }^{15}$ the joint transmission of sound and video from the work of A. Schildt / A. Sywottek (eds.), Modernisierung im Wiederaufbau. Die westdeutsche Gesellschaft der 5 oer Jahre, Bonn 1993.

14 A. Milward, The European Rescue of the Nation State, London 1992.

15 Other examples of «radical innovations» are the transition from electronic tubes to transistors or from analogue to digital. For a concise and smart introduction to various theories of innovation see H. Braun-Thürmann, Innovation, Bielefeld 2005 . 
signals as «television» was a rather «logical consequence» of wireless technology. It is no wonder that early on, television was described as «Bildfunk» (Germany), «beeldradio» (Netherlands) or «wireless vision». The long history of technical exploration with television - from the first experiments with moving picture telegraphs in the I880s to the implementation of electro-mechanical television systems in the I930s - rooted television in the technological imagination long before it arrived. ${ }^{16}$ During this long experimental phase, television witnessed several deaths and resurrections. ${ }^{17}$

The first television boom, most visible in the many public demonstrations of the new device as «technology of attraction» at industrial or radio fairs, ${ }^{18}$ ended in the early ig3os. The successful popularisation of television had fuelled the hope that the implementation of television was just around the corner. But it proved to be a long and winding road from successful experimentation with electromechanical television devices based on the Nipkowdisc to the building of a professional television infrastructure. Not surprisingly, critical observers of television's development began to question the euphoric promises of early television pioneers and enthusiasts in the late I920s. Eduard Rhein, a German who was one of the first radio and television critics wrote in the journal Fernsehen: «There we are standing, we, who looked up to the new coming miracle with wide eyes, quite disappointed, perhaps angry. What the daily press shouted at us phrases! It is nothing! Whether progress is recorded, proved with differentials, integrals, slide-rules, curves - we can't see it!» The German audience, which was first introduced to television at the Berlin broadcasting fairs in 1927 and 1928, longed for visible results. ${ }^{19}$ As the American journalist Alva Johnston wrote, television had «suffered from its own prophets": «Back in the 20's it was taken for granted that television was only a year or two away. Warnings or difficulties had no effect; scientists were regarded as gods who could solve all problems with a turn of the wrist. [...] Too much prophecy has made the magic box something of an anticlimax.» ${ }^{20}$ Considering that it took television 75 years to develop from a subject of visionary speculations to experimental object and finally household

16 M. Breton / A.-K. Weber (eds.), La télévision du téléphonoscope à youtube. Pour une archéologie de l'audiovision, Lausanne 2009.

17 For a detailed reconstruction of the different phases in the long and complicated process of institutionalisation of television in the Netherlands see A. Fickers, «De stenige weg van de beeldradio in Nederland», in: H. Wijfjes / S. de Leeuw / B. Hogenkamp (eds.), De eeuw van beeld en geluid, Hilversum 20II, 82-II9.

18 A.-K. Weber, «Du dispositif spectaculaire au poste standardisé: l'exposition de la télévision aux Funkausstellungen berlinoises, I928-I939», in: O.
Lugon (ed.), Médias et expositions, Lausanne 20II (forthcoming).

19 M. Elsner / T. Müller, «The early history of German television: the slow development of a fast medium», in: Historical Journal of Film, Radio and Television Io (1990) 3, I93-220.

20 A. Johnston, «Television's Here», in: The Saturday Evening Post, 6 May I939, 8, quoted from J. Garth, «Dangling the dream? The presentation of television to the American public, I928-1952», in: Historical Journal of Film, Radio and Television I4 (I994) 2, I37. 
consumer technology, the emergence of television must be interpreted as the result of a long-lasting evolutionary process rather than as a «technological revolution». ${ }^{21}$

\section{Conservative Institutional Patterns of Television Development}

From an institutional perspective, television grew within the existing organisational patterns of radio broadcasting. Nearly all over the world, television took shape within the existing model of radio broadcasting institutions, in all their possible varieties (commercial, public service or dual). ${ }^{22}$ These institutional environments influenced the way in which television was envisioned, organised, regulated, financed, controlled, managed, produced, programmed, broadcasted, and even received. As the public service model became the dominant model of radio broadcasting in Western Europe, television as an audiovisual extension developed within this existing «structuring frame». ${ }^{23}$ The four paradigmatic forms of national public service broadcasting institutions in Western Europe were the paternalistic model of the BBC, the federal model of West Germany, the centralist model of France, and the pillarised model of the Netherlands. But the meaning of the term «public service» varied considerably. ${ }^{24}$ The British model of public broadcasting as embodied by the BBC - a model that many countries in the world admired - can best be characterised as paternalistic, aiming at educating, informing and entertaining people in a socially responsible, culturally dignified and politically «neutral» way. ${ }^{25}$ What distinguished the British model was not so much this paternalistic vision of television as a public service (similar attitudes can be found in many other countries) but rather the installation of a so-called dual system in I954. The establishment of the Independent Television Authority (ITA), which controlled a network of private television production companies that provided the programmes for the commercial station ITV, was the specifically British outcome of long-lasting debates about the nature of television as a «public service». ${ }^{26}$

France had a rather different idea of a public service broadcasting organisation and instituted a centralised model of public service with Paris (and literally the Eiffel Tower) as the radiating heart, and the state or government as the central authority. ${ }^{27}$ The control over radio and television broadcasting in France clearly

21 The first reference to television as revolutionary is to be found in R. Lee, Television: The Revolution, New York I944.

22 A. Fickers, «Broadcasting», in: A. Iriye / P. Y. Saunier (eds.), The Palgrave Dictionary of Transnational History, Basingstoke 2009, I06-I09.

23 Stéphane Olivési speaks of radio as the «cadre structurant» for the development of television. See S. Olivési, Histoire politique de la télévision, Paris I998, пi6.

24 P. Scannell, «Public Service Broadcasting: the His- tory of a Concept», in: A. Goodwin / G. Whannel (eds.), Understanding Television, London I990, II29.

25 On the radiance of the «BBC model» in the world see A. Briggs, The BBC in World Perspective. BBC Lunch-time Lectures, London I977.

26 C. Johnson / R. Turnock (eds.), ITV Cultures. Independent Television over 50 Years, Maidenhead 2005.

27 J. Bourdon, Haute Fidélité. Pouvoir et télévision 1935-1994, Paris I994. 
went beyond the exertion of authority in infrastructural and administrative matters. There was a broad consensus amongst politicians of the Fourth Republic that radio and television were to be used as legitimate instruments for the control and formation of public opinion. This view gained even more momentum after General de Gaulle came to power in I958. ${ }^{28}$ While the governmental instrumentalisation of television in France was seen as legitimate in the highly politicised public debates of the chaotic Fourth Republic (at least by those in power), the western part of defeated Germany saw a different development. In West Germany, a federal model reemerged from the post-war occupation zones, designed to prevent any governmental control or abuse of the medium. While often seen as the result of American and British influences, the new broadcasting landscape was in fact a reconstitution of the federal structure of early Weimar radio broadcasting. ${ }^{29}$ In addition to the French or West German example, both strongly reflecting the geopolitical structures of their countries, other models were developed, such as the Dutch «pillarised» public service model. ${ }^{30}$ Here, the state (specifically, the Ministry for Post \& Telecommunication) as in all other countries controlled the transmission infrastructure of the national television network, but the programming was done by five different broadcasting organisations, representing the major religious and ideological groups in Dutch society. ${ }^{31}$ What ties these different variations of public service broadcasting models together, especially when compared to the commercial model of the United States, is the strong influence of political visions of television as an instrument for nation building and cultural radiance.

\section{Televisual Aesthetic and the Remediation of Formats and Genres}

With the arrival of television, broadcast officials, governmental administrations and industrial stakeholders in most countries debated whether television should be integrated into radio broadcasting, or if it should be «outsourced» as a commercial activity beyond the responsibility of the state. During the «experimental phase», ${ }^{32}$ broadcast organisations and within them television technicians and programme producers experimented with a multitude of potential uses and audiences for television. This search for the medial identity of the new medium and its potential as a new form of mediated communication had its roots in the early days of television technology. But with the start of regular television broadcasts in GerLes années cinquante, Paris 1999.

29 The centralisation of radio broadcasting in Germany was a result of the reorganisation of the broadcasting system by the National Socialists. See A. Diller, Rundfunkpolitik im Dritten Reich, München I980. For a concise history of German television (both East and West) see K. Hickethier, Geschichte des deutschen Fernsehens, Stuttgart 1998.
30 H. van den Heuvel, Nationaal of verzuild. De strijd om het Nederlandse omroepbestel in de periode 19231947, Baarn 1976.

31 H. Newcomb (ed.), Encyclopedia of Television, New York 2004, I63I-I633.

32 G. Delavaud / D. Maréchal (eds.), Télévision: le moment expérimental, Paris $20 \mathrm{II}$. 
many and Great Britain in the mid-I930s, experimentation with television shifted from an amateur and industrial environment mainly concerned with television as a new technology to a professional radio environment, interested in the experimentation with television as a new medium. In pre-war Great Britain, where regular television broadcasts had started in 1936, the small but dedicated BBC television staff not only struggled with the invention of a new televisual style, ${ }^{33}$ but also with the delimitation of viewing expectations by the new television public. In order to test if television programmes would also work on sound broadcasting when accompanied with additional commentaries at the beginning of a transmission, the BBC started experimenting with the simultaneous transmission of television programmes on the vision and sound broadcasting channels in 1938. At the same time, they tested how viewers would react if the main radio news was retransmitted after the end of television broadcasts - an idea that grew out of the belief that television viewers would feel like they had missed important information while sitting in front of the screen. ${ }^{34}$

The negotiation of the medial identity of television drew not only on radio but also on cinema. Cinema probably came closest to what the average person expected of the new medium. As the popular discussions of the future of television in Dutch radio magazines and newspaper articles show, expectations of how television programmes should appear clearly derived from people's familiarity with film. Although regular (experimental) television service didn't start in the Netherlands until I95I, the late I930s saw an intense debate on which needs television - if it should ever develop into a mass medium - would have to fulfil. A radio magazine article from March I935 framed the horizon of expectation in terms of the cinematic dispositif: «We, spoiled children, will no longer be satisfied with something that is just half ready. We cannot - probably unconsciously - help but compare television to film.» ${ }^{35}$ In a series of I9 articles published in the Dutch radio magazine AVRO Radiobode between March and July I936, author Jan Geertsen critically reflected on the chances and pitfalls of television. Even if all the major technical and economic problems of television broadcasting could one day be solved, he concluded, in a sceptical tone, that the quality of the programmes would determine whether or not the new medium would be accepted by the critical public: «Only when all the technical and economic challenges of television are solved, only then the ear will be followed by [...] the eye. But what will the eye ask for? A lot! The eye represents the quality standards of the public. And these standards are based on the viewing experiences made with film and the listening habits of radio audiences.» ${ }^{36}$

33 See J. Jacobs, An Intimate Screen: Early British Television Drama, Oxford 2000.

34 See: BBC Written Archives (Caversham), signature $\operatorname{Ti} 6 /{ }_{5} \mathrm{~K} / \mathrm{I}$.
35 «Televisie», in: NCRV Omroepgids II (09.03.1935) IO, 20.

$36 \ll, \mathrm{Na}$ het oor ... het oog! Final article of Jan Geertsen», in: AVRO Radiobodeg (I936) 30, 5. 
First cover of the BBC listener magazine Radio Times 1923. Source: BBC Written Archives, Caversham.

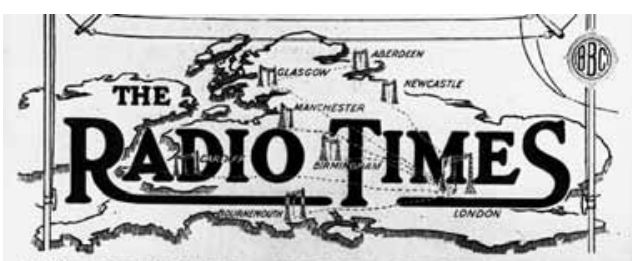

THE OFFICIAL ORGAN OF THE B.B.C.

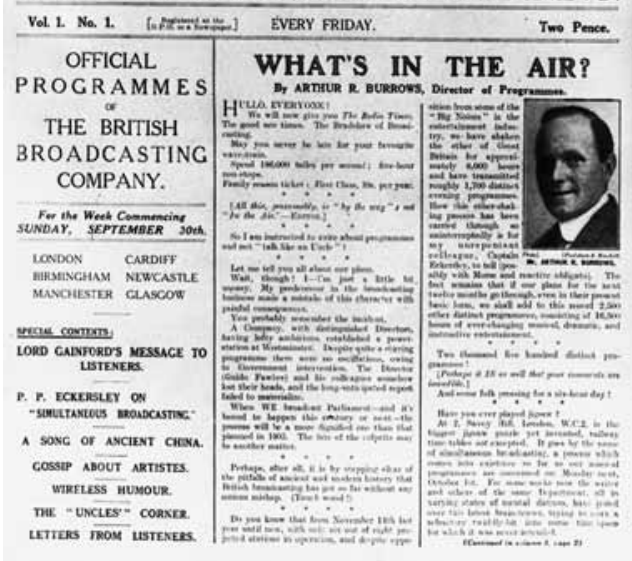

Thus, viewers> expectations were not only framed by listening and viewing habits. The ground for the intellectual appropriation of television was prepared by the critical debate of the new medium in radio magazines and newspapers. The radio magazines, regardless of their status as official organ of broadcasting organisations line the Radio Times of the BBC or private publications like the German Hör $z u$ !, were of crucial importance for the popularisation of television and offered a forum for the critical discussion of the identity of the new medium. As mediating interfaces between the broadcasting institutions and millions of listeners and viewers, radio magazines showcase the long and winding road of the public negotiation of television's place in the mass media ensemble. ${ }^{37}$ The readers of popular radio magazines were constantly confronted with journalistic conceptions of what television should be, how it should look or what its political and cultural mission ought to be. In doing so, journalists and critics constructed or invented an ideal type of «television viewer», reflecting their own experiences with and expectations of the new medium. ${ }^{38}$ These expectations were not only framed by their familiarity

37 L. Seegers, Hör zu! Eduard Rhein und die Rundfunkprogrammzeitschirften 1931-1965, Potsdam 2003. For France see J. Dakhlia, Histoire de la presse de television en France de 1950 à 1995, unpublished PhD dissertation at Ecole des Hautes Études en Sciences Sociales, Paris I998; C. Blan- din, «Lémergence de la presse spécialisée», in: Delavaud / Maréchal, Télévision, 380-390.

38 M.-F. Chambat-Houillon, «L'avènement de la télévision. La critique télévisuelle entre I950 et I955", in: Delavaud / Maréchal, Télévision, 4I4-430. 
with the intrinsic qualities of the medium of sound broadcasting (like the principle of «flow» in programming), but also by their «viewing socialisation» with the medium of film. ${ }^{39}$

From an intermedial perspective, the interference between television and film constituted another important site of negotiation of TV's identity. The question of whether television programmes should be shown in cinemas or theatres led to battles over the appropriate place for television consumption, and debates about legitimate forms of public entertainment and their distribution..$^{40}$ While broadcast institutions thought movie theatres were attractive venues for the public distribution and collective experience of live television programmes, the film industry tried to defend its territory and worried about the broadcasting of films on TV. This competition between film and television led to an interesting intermedial mixture in the United States with the advent of so-called «Television Theaters», where stakeholders of the Hollywood movie fabric successfully, albeit temporarily, gained a foothold in the emerging television business..$^{41}$ By contrast, in Europe the situation was characterised by a clearer separation of the two media and by many attempts to establish an unambiguous demarcation of production spheres and distribution channels. ${ }^{42}$ An intertextual perspective, however, would reveal many cross-references between the two mediums. ${ }^{43}$

But the intimate relationship between radio, television and cinema was not limited to the institutional or technical level. Looking at media personnel, it is impossible to deny the massive migration of radio, film and theatre professionals to the rapidly expanding business of television. ${ }^{44}$ Both technicians and presenters moved from radio to television, importing their knowledge and practical experiences. Costume and stage designers were hired from theatres, and the art of make-up - which because of the extreme temperatures in the brightly lit studios was of great importance in the early days and became even more crucial with the introduction of colour television in the late sixties - was imported from cinema. ${ }^{45}$ It is not surprissation», in: R. Vollbrecht / C. Wegener (eds.), Handbuch Mediensozialisation, Wiesbaden 2010, 24I-25I. On the concept of «flow» as a metaphor for broadcasting see J. Gripsrud, «Television, broadcasting, flow: key metaphors in TV theory», in: C. Geraghty / D. Lusted (eds.), The Television Studies Book, London I998, I7-32.

40 S. Zielinski, Audiovisions: Cinema and Television as Entr'actes in History, Amsterdam 1999.

41 W. Boddy, Fifties Television. The Industry and Its Critics, Chicago ı990; T. Balio (ed.), Hollywood in the Age of Television, Boston I990; M. Hilmes, Hollywood and Broadcasting: From Radio to Cable, Urbana I999.

42 S. Holmes, British Tv and Film Culture in the 1950s,
Bristol 2005; J. Cluzel (ed.), La télévision a-t-elle tué le cinéma?, Paris 2005; T. Beutelschmidt, Kooperation oder Konkurrenz? Das Verhältnis zwischen Film und Fernsehen in der DDR, Berlin 2009.

43 V. Paci, «Entre promesse et menace: le cinéma regarde la télé», in: Delavaud / Maréchal, Télévision, 525-532.

44 See the autobiographical study of L. Akkermans, Televisie. Beginjaren van een nieuw beroep, Amsterdam 2003.

45 L. Spigel, «Setting the Stage at Television City: Modern Architecture, TV Studios, and Stage Design», in: L. Spigel, TV by Desgin. Modern Art and the Rise of Network Television, Chicago 2009, IIOI43; S. de Leeuw, De man achter het scherm. De televisie van Erik de Vries, Amsterdam 2008. 
ing, then, that the migration of personnel also involved a transfer of knowledge and routines. This is most evident when looking at the repertoire of early television programming, which mainly consisted of adaptations of theatre plays (or their live transmission) or radio programmes (talk shows, quiz shows, soap operas, news, series, etc.), and the integration of films. As François Jost has demonstrated, the programming at the French national station RTF (Radio Télévision Française) between I947 and I95I was characterised by two complementary phenomena: the «televisualisation» of original radio programmes and the «cinematisation» of television. ${ }^{46}$ These two phenomena can be observed in many other European countries as well (although they are not always well-documented). Successful radio formats were adapted and many films imported - not least because the emerging television departments, part of institutions dedicated to sound broadcasting, were rather short on funds. The figures compiled by Jost also highlight the steady growth of news production. News became the genre that most adequately fulfilled the promise of television: to allow «distanced medial participation» in relevant political and social events. ${ }^{47}$

\begin{tabular}{|c|c|c|c|c|}
\hline Genre & & $\begin{array}{c}\text { Remediated Radio } \\
\text { Programmes }\end{array}$ & Films & News \\
\hline \multirow{5}{*}{$\begin{array}{l}\text { Percentage } \\
\text { of this genre } \\
\text { in total programme } \\
\text { output }\end{array}$} & 1947 & 31,4 & 25,0 & 13,4 \\
\hline & 1948 & 33,6 & 32,1 & 11,0 \\
\hline & 1949 & 23,0 & 21,5 & 20,9 \\
\hline & 1950 & 12,0 & 12,8 & 43,0 \\
\hline & 1951 & 10,9 & 16,3 & 36,1 \\
\hline
\end{tabular}

A quality that distinguished television from other media was its live transmission, since the first professional recording technologies for video signals only appeared in the late I950s. The inability to videotape imposed a rather limited televisual aesthetic: static images and limited studio settings predominated. Many early television formats mirror this limited aesthetic potential of the new medium and thus relativize the creative potential of television as a new art form. ${ }^{48}$ The «television of attraction» was reduced to a small number of outside broadcasts - especially sporting events. ${ }^{49}$ Moreover, up until the late sixties, it was radio that covered most of

46 F. Jost, «Logique des genres de la télévision des débuts», in: Delavaud / Maréchal, Télévision, 4I4-430.

47 A. Fickers / B. Kester, «Veel nieuws - weinig geschiedenis. Een historiografisch essay over international televisienieuws», in: Tijdschrift voor Mediageschiedenis 8 (2005) 2, 4I4-430.

48 K. Dowler, An historical inquiry into the political and cultural context for the emergence of a television aesthetic in the Nineteen-fifties, PhD dissertation at the Univ. of Montréal I993.

49 R. Hudson, Inside Outside Broadcasts, Newmarket I993; F. Wille, «Le spectacle sportif télévisé. Logiques d'innovation et de promotion», in: Delavaud / Maréchal, Télévision, 246-256. 
these events «live», whereas television offered short filmed sequences in the evening news programmes. Technical hurdles, financial implications and - most of all - the restricted daily hours of television programming made television much less of a live medium than radio was. Other technological restraints - the limited light sensitivity of cameras, their heavy weight and the difficulties of catching the sound of dialogue without having the microphones in the picture - all contributed to a depleted visual aesthetic of the medium of television compared to film. ${ }^{50}$

What has often been described as a typical or original quality of television the planned combination and sequential composition of different genres and formats or «flow» was in fact typical for radio broadcasting. The programming and scheduling of early television can instead be interpreted as a successful remediation of the existing repertoire of formats, genres and programmes in the fields of mediated information, education and entertainment. This in a literal sense «conservative» (preserving) function of television was one of the big challenges in the search for a distinctive identity of television in the mass media ensemble. In reassessing the «newness» or «distinctiveness» of early television as a new medium, MarieFrance Chambat-Houillon comes to the conclusion that one has to differentiate between two «births» of television: a first one representing the strong intermedial identity of television as an emerging medium (characterised by radio and theatre adaptions and the incorporation of films), and a second one based on the creative development of a distinct televisual style, mainly characterised by a specific aesthetic of liveness. ${ }^{51}$ It was only during the second birth that television succeeded in adding an «original» contribution to the existing mass media ensemble, both in terms of content and mediated experiences.

\section{Television as Mirror and Multiplier of Conservative Values}

If the advent of television was deeply embedded in existing institutional patterns, and aesthetic and stylistic conventions, how could TV function as an agent of cultural modernisation? Did television really have a modernising effect in post-war European societies, or did it promote conservative norms and values, both as cultural form and social institution? I argue the latter. The medium was a mirror and catalyst of the conservative Zeitgeist during the age of «reconstructive modernisation» in post-war European societies..$^{2}$ The televised «norms and values» in the long I950s reflected conservative political and moral beliefs that dominated most post-war European societies. ${ }^{53}$ Family series and variety shows reproduced and

50 E. Sandon, «La télévision expérimentale à Alexandra Palace. La BBC et sa programmation de variétés», in: Delavaud / Maréchal, Télévision, I63-I78.

51 M.-F. Chambat-Houillon, «L'avènement de la télévision», in: Delavaud / Maréchal, Télévision, 424.

52 K. Hickethier, «Television and the social transformation in the Federal Republic», in: K. C. Führer /
C. Ross, Mass Media, Culture and Society in Twentieth-Century Germany, Basingstoke 2006, I29-I45; C. Shaw, «Taste, Decency, and Standards», in: A. Smith (ed.), Television: An International History, Oxford I995, I22-I3I.

53 S. Holmes, Entertaining television: the BBC and popular television culture in the 1950s, Manchester 
amplified the post-war ideal of family togetherness and depoliticised spare time entertainment. ${ }^{54}$

The home became the preferred place to consume mediated electronic entertainment and information, and the slow but steady rise of television challenged the predominance of cinema as the privileged form of outside visual entertainment. Despite the fact that the early days of television were characterised by a high degree of «public viewing" 55 and a long period of uncertainty about screening technology (large-screen projection television to be shown in cinemas, or small screen sets for the home $)^{56}$, domestic viewing was seen as the future of television broadcasting. The enormous success of television in the United States, where television had always been viewed as a medium for home entertainment and not for public information or education, convinced most European critics that the future of television was a domestic one. ${ }^{57}$ As central pillars in the moral recovery of post-war nation states, the family as «societal nucleus» and television as a new «electronic hearth» of the home formed a successful and powerful alliance, and played an important role in the process of «reconstructive modernisation». ${ }^{58}$ It was only during the second half of the I960s and in the I970s that television developed its repertoires of critical journalism, establishing it as the primary medium for public social and political debate. As Chris Vos has shown, television - especially in matters of information and news - started as a loudspeaker or propagandist of governmental interests and only slowly took a critical stance toward the political powers. ${ }^{59}$ Outside of

2008; E. Smulders, «Het glazen huis der openbaarheid. Televisie in de jaren vijftig: de moeizame groei van een modern medium», in: P. Luykx / P. Slot (eds.), Een stille revolutie? Cultuur en mentaliteit in de lange jaren vijftig, Hilversum I997, 249-280; A. Fickers, «Radio und Fernsehen als nationale Sozialisierungsinstanzen? Der Rundfunk im Rahmen der westdeutschen und französischen Wiederaufbaumodernisierung der I950er Jahre», in: H. Miard-Delacroix / R. Hudemann (eds.), Wandel und Integration. Deutsch-französische Annäherungen der fünfziger Jahre, München 2005, 29I-307.

54 K. Hickethier, Das Fernsehspiel der Bundesrepublik: Themen, Form, Struktur, Theorie u. Geschichte; 1951-1977, Stuttgart I980; P. Goetschel, «Les dramatiques télévisées, lieux d'apprentissage culturel et social dans la France des Trentes Glorieuses?», in: E. Cohen / M.-F. Lévy (eds.), La télévision des Trentes Glorieuses, Culture et politique, Paris 2007 , II3-I44; C. Bartz, «Normativité et normalité du discours allemand sur la télévision dans les années I950», in: Breton / Weber, La télévision du téléphonoscope à youtube, I97-2I2.

55 Cafés, bars, pubs and, in a more educational setting, schools and buildings of public administrations have all been «early adaptors» of television.
Local «television clubs» emerged to gather television amateurs and to discuss technical and cultural issues related to the new medium. See the rich empirical UNESCO study by J. Dumazdier, Télévision et éducation populaire. Les télé-clubs en France, Paris I955.

56 C. Meyer, Der Eidophor. Ein Großbildprojektionssystem zwischen Kino und Fernsehen 1939-1999, Zürich 2009 .

57 A. Fickers, «Presenting the «Window on the World to the World. Competing Narratives of the Presentation of Television at the World's Fairs in Paris (I937) and New York (I939)», in: Historical Journal of Film, Radio and Television 28 (2008) I, 29I-3IO.

58 L. Spigel, Make Room for TV. Television and the Family Ideal in Postwar America, Chicago I992; M.-F. Lévy, «Television, family and society in France I949-I968», in: Historical Journal of Film, Radio and Television I8 (I998) 2, I99-212; S. Briggs, «Television in the home and family», in: Smith, Television, Io9-I2I.

59 C. Vos, «Van propagandist tot makelaar. De uitvinding van de Nederlandse televisiejournalistiek», in: J. Bardoel (ed.), Journalistieke cultuur in Nederland, Amsterdam 2002, 269-286. 


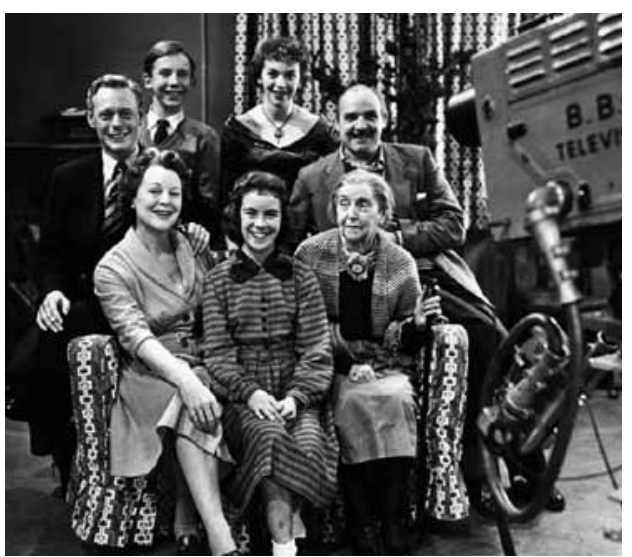

The first «TV family» of British television:

The Grove Family (produced and transmitted live by the BBC 1954-1957).

Source: BBC Audiovisual Archives, Brentford.

Britain, one had to wait until the late I96os before political magazines and current affair programmes developed a critical journalistic attitude and established themselves as important actors in the political public sphere. ${ }^{60}$

Taken all together, the conservative nature of television as a new medium becomes evident. The historicisation of the emergence of television from a technical, intermedial, institutional and cultural perspective allows one to interpret the advent of television as an evolutionary process, characterised by conservative patterns of development. While contemporaries in the I950s believed in TV's revolutionary potential as a «window on the world), our approach challenges the common ideological connotations of «newness» inscribed into television as a technology and cultural form. ${ }^{61}$ Instead of «bringing the world into the home» - as was repeatedly suggested by television advertisements - television was in fact instrumental in shrinking «the world» to the political borders and social space of the nation. It did so both for techno-political and cultural reasons.

G. Lampe, Panorama, Report und Monitor. Geschichte der politischen Fernsehmagazine 1957-1990, Konstanz 2000; P. Holland, The Angry Buzz. «This Week» and Current Affairs Television, London 2006; K. Malka-Levy, Les emissions politiques à la television en France. Réflexions sur la place et le rôle des émissions à vocation politique dans les grilles de programmes, unpublished PhD dissertation Paris 200I; C. von Hodenberg, Konsens und Krise. Eine
Geschichte der westdeutschen Medienöffentlichkeit 1945-1973, Göttingen 2006.

61 For a critical reflection and systematic analysis of the ideological connotations of new media discourses see M. Lister et al., New Media. A Critical Introduction, London 2009, especially 9-IO4. 


\section{A Global Time-out? Television in Search of the Nation}

The popular press and the advertising industry celebrated the advent of television as the final realisation of an old dream of mankind: seeing into the distance. The German term for television, Fernsehen, literally refers to this act of seeing into the distance. From the I87os on, terms like «seeing by electricity» or «distant electric vision» circulated in scientific and popular journals, and television seemed like yet another technical miracle to be realised in the very near future. ${ }^{62}$ Despite the fact that it took more than 60 years to turn the vision of television into reality, the central metaphor of «window to the world» did not lose any of its appeal - at least when looking at the iconography of television advertisements in the I950s.

As the first Philips advertisement from I954 demonstrates, the slogan of the «window on the world» was not only used as a literary metaphor, but often as a central motive in the invention of a televisual iconography in advertising. ${ }^{63}$ The screen turned into a magic mirror or translucent interface, inviting the viewer to become an «armchair Columbus» and to stand «face to face» with the world. The DuMont advertisement published in the magazine The Billboard in August I944 stated: «You'll sail with television through vanishing horizons into exciting new worlds. You'll be an intimate of the great and near-great. You'll sit at speakers tables at his-
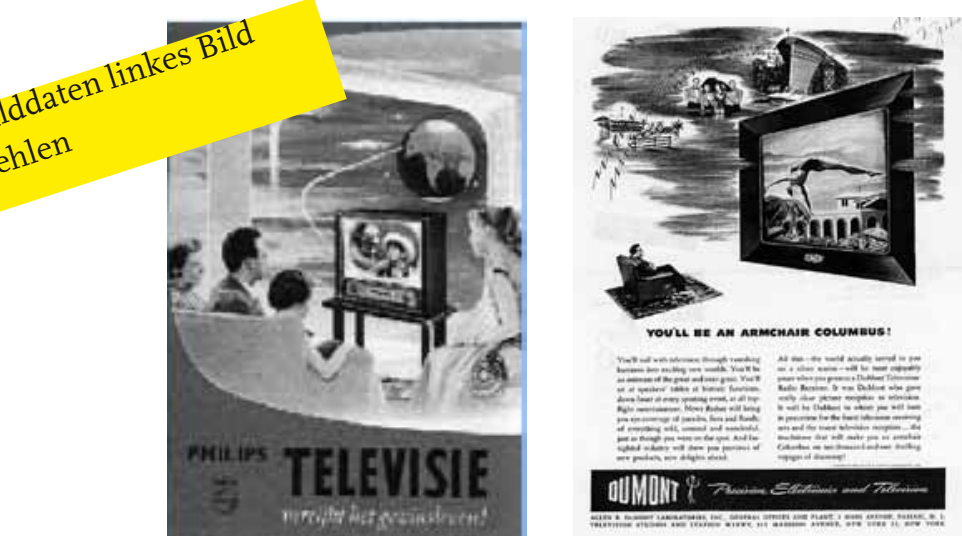

Left: Philips television advertisement from 1954 using the metaphor of television as «window to the world» as artistic theme. The poster was developed by the Philips advertisement department in Eindhoven for the start of Eurovision in July 1954. Source: Philips Company Archives, Eindhoven. Right: «You'll be an armchair Columbus». DuMont television advertisment from 1944. Source: The Billboard (19.08.1944), p. 9.

62 D. Daniels, Kunst als Sendung. Von der Telegrafie zum Internet, München 2002, 76-90 and A. Duisters, «Het kijkglas. Negentiende-eeuwse fantasieen over televisie», in: Tijdschrift voor Mediageschiedenis 8 (2005) I, 63-85.

63 S. Kosareff, Window to the Future. The Golden Age of Television Marketing and Advertisement, San Francisco 2005. For the spread of the metaphor of the «window» in Germany see C. Damann, Stimme aus dem Äther - Fenster zur Welt. Die Anfänge von Radio und Fernsehen in Deutschland, Köln-Weimar-Wien 2005, 78-89. 
toric functions, down front at every sporting event, at all top-flight entertainment. News flashes will bring you coverage of parades, fires and floods, of everything odd, unusual and wonderful, and bring them to you as though you were there [...] All this - the world actually served to you on a silver screen - will be most enjoyably yours when you own a DuMont Television-Radio Receiver. [...] the touchstone that will make you an armchair Columbus on the thousand-and-one thrilling voyages of discovery!» 64

As a «medial duplication of the world» (Theodor W. Adorno), television seemed to offer a new and privileged entry into reality. ${ }^{65}$ The visual aspect of television gave it - at least in the eyes of early television critics - a quality in the perception of reality that transcended the sense of medial participation offered by other media. It seemed to offer «more reality» than radio or the printed press. ${ }^{66}$ This exaggeration of the newness and revolutionary potential of television is a recurrent topos in the long history of «new media». Public discourse surrounding the emergence of a new medium usually follows stable patterns, characterised by exaggerated hopes and fears about the impact of the newcomer on society and culture. ${ }^{67}$ Television advertising reproduced many of the slogans originally developed for the promotion of radio broadcasting. During the I920S, radio was presented as an «ear to the world», bringing the world into people's homes. ${ }^{68}$ It came with the «fascination of availability», and promised simultaneity and the «opening of the home to the world». ${ }^{69}$
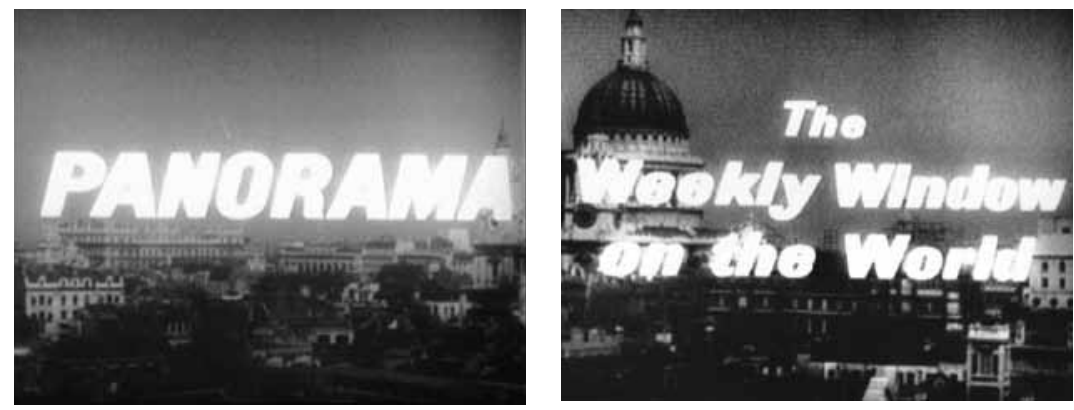

Screenshots of the BBC current affair programme »Panorama: The Weekly Window on the World«. Source: BBC Audiovisual Archives, London.

64 You'll be an armchair Columbus, DuMont advertisement published in The Billboard, I9.08.1944, 9 .

65 T. Adorno, Eingriffe. Neun kritische Modelle, Frankfurt a. M. 1963, 69.

66 J. Sconce, Haunted Media. Electronic Presence from Telegraphy to Television, Durham-London 2000, I3I.

67 W. Boddy, New Media and Popular Imagination. Launching Radio, Television, and Digital Media in the United States, Oxford 2004; L. Gitelman, Al- ways Aready New. Media, History, and the Data of Culture, Cambridge-London 2006.

68 C. Lenk, Die Erscheinung des Rundfunks. Einführung und Nutzung eines neuen Mediums 1923-1932, Opladen I997, II6.

69 K. Maase, «Jetzt kommt Dänemark». Anmerkungen zum Gebrauchswert des frühen Rundfunks», in: E. Lersch / H. Schanze (eds.), Die Idee des Radios. Von den Anfängen in Europa und den USA bis 1933, Konstanz 2004, 60. 
In contrast to radio, early television never fulfilled the promise of being a window to the world. Instead of reaching out for the world, television was very much focused on the nation as the main addressee and object of televisual representation. From a media perspective, the long I950s witnessed an interesting reshaping of the broadcasting sphere. While television gradually expanded its coverage from a local to a regional and finally a national dimension, radio broadcasting - because of the emergence and implementation of FM radio - developed from a transnational and national medium into a more regionally or locally structured one. ${ }^{70}$ In fact, the «golden age» of television marks a phase of global time-out in broadcasting. Both the strict national borders of television infrastructure and the regionalisation of radio with the successful implementation of FM radio turned the transnational broadcast landscape of the interwar years into a rather closed national broadcasting space in the post-war years. ${ }^{71}$ Sure, this structural change of the broadcast sphere occurred at different rates and with varying degrees of implementation. But a comparative topographical analysis of the coverage of the different broadcast media points to a structural change in the audiovisual mass media landscape in the I950s and I960s. Long and medium wave radio broadcasting had established a transnational communication space in Europe in the I920s, and the introduction of short wave radio in the I930s had made radio a truly global medium. ${ }^{72}$ But with the introduction of $\mathrm{FM}$ radio and television, broadcasting entered the era of very high (VHF, 30-300 MHz) and ultra-high frequencies (UHF, $0,3-3 \mathrm{GHz}$ ). As the spread of electromagnetic waves diminishes with increasing frequency, the propagation of both FM radio and television signals is much shorter than with AM (long, medium and short wave) radio signals. Without either a cable network or a dense network of so-called relay stations where the VHF or UHF signals are being received, amplified and retransmitted, nationwide coverage would not be possible. ${ }^{73}$

The main preoccupation of those bodies responsible for the transmission of television signals during the I950s - mainly the national post and telecommunication authorities - was therefore to gradually expand the television signals> coverage of national territories. This was both a technical challenge and a strategic mission. Because of the limited spread of VHF and UHF frequencies, television signals Medienumbrüche in sozialgeschichtlicher Perspektive», in: A. Schildt / D. Siegfried / K. C. Lammers (eds.), Dynamische Zeiten. Die 19 Goer Jahre in den beiden deutschen Gesellschaften, Hamburg 2000, 673-694.

71 C. Henrich-Franke, «Die Erfindung NordrheinWestfalens auf der Ultrakurzwelle - Transnationale technologische Entwicklungen und die Fragmentierung des Europäischen Rundfunkraums», in: Geschichte im Westen I (2010), 7-35.

72 For the transnational dimension of European sound broadcasting in the interwar years see S. Lommers, Europe - On Air: Broadcasting Projects during the Interwar Years, Amsterdam 20II (forthcoming).

73 See A. Fickers, Der «Transistor» als technisches und kulturelles Phänomen. Die Transistorisierung der deutschen Radio- und Fernsehindustrie 1955-1965, Bassum I998. 
could only be received in an average ambit of $80 \mathrm{~km}$ (depending on the geophysical nature of the landscape). In order to build up a national television network, a chain of strong regional transmitters and many relay stations were needed. As the example of Great Britain shows, the development of a nationwide television transmitter infrastructure was dependent on three factors: The budget of the Post \& Telecommunication administration; the decision of whether to build the network on cable or based on radio links; and the establishment of a national broadcasting institution able to provide the programmes needed to boost the attraction of the new medium. The BBC pushed strongly for national coverage «at the earliest practicable moment», ${ }^{74}$ and the Television Advisory Committee (TAC) finally backed this position by recommending a stepwise expansion of the national television infrastructure. The goal of the TAC was to bring television to approximately 40 million viewers in 1954 (i.e., 80 per cent of the population). ${ }^{75}$ As the following map shows, a network of high power transmitter stations (marked as BBC transmitter stations) and radio repeater stations were to ensure national coverage through a combination of cable and radio links.

The fast development of a national television infrastructure was also of strategic interest for the radio industry. The technical experience provided by the establishment and operation of a network of television links would be «most valuable both in relation to the home service and as a selling point in the export of television apparatus», Sir Alan Barlow, second joint secretary of treasury suggested in I946. Keeping Britain «in the forefront in development of television» and to «maintain our pre-war head over U.S.A. in television» would deliver «substantial export guarantees». ${ }^{76}$ The economic promises of television as a new industry provoked a techno-political battle between the major players in the European television landscape. ${ }^{77}$ Triggered by a «first mover» logic, or the notion that being first on the market would considerably enhance a country's chances of successfully disseminating and implementing a specific television system, all the major players in the European television industry and administration fiercely promoted their line standard for black and white television in Europe. While Britain advocated its pre-war standard of 405 lines, the French introduced a «high definition» standard (8I9) lines) in I949. The influential Dutch radio manufacturer Philips promoted a $567-$ line system, developed by the multinational as a European variant of the American 525-line system. Yet another alternative, 625-line system, originally developed by

74 «Proposals to extend the television service» / Note by the BBC for the Television Advisory Committee, 3r.o8.r949 (3 pages), in: National Archives, signature T 219 / 422.

75 «Report on television expansion» (as finally approved and submitted to the Postmaster General) by the Television Advisory Committee, 2I.09. I949 (3 pages), in: National Archives, T 219 / 422.
76 Note of Sir Alan Barlow to Mr. Harvey, London 30.04.I946 (4 pages), in: National Archives, signature: T 219 / 422 .

77 A. Fickers, «Politique de la grandeur» versus «Made in Germany». Eine politische Kulturgeschichte der Technik am Beispiel der PAL-SECAM-Kontroverse, München 2007, 65-100. 
Russian television engineers, was backed by West Germany and Switzerland. The result of this techno-nationalist struggle for television standards was a technically fragmented European television landscape. The different line standards seriously complicated the transnational radiance of television programmes and the use of equipment, which presented an obstacle to the ambitions of early Eurovision enthusiasts. $^{78}$

The post-war line standard debate must be interpreted as a techno-political conflict of technical, symbolic and economic importance. Because of the network structure of television as a large technical system, the definition of a line standard directly impacted the technical parameters and characteristics of the production, transmission and reception technologies of television. Fuelled by techno-nationalist reasoning, all the major players in the field of television technology promoted their standard with a strange mixture of protectionist (securing the home market) and expansionist (exporting domestic technology) arguments. This shows how economic, industrial, political and even cultural norms and values are inscribed into the apparently neutral characteristics of a technical standard. ${ }^{79}$ This technopolitical instrumentalisation of early television technology complicated the development of a transnational European television infrastructure and catalysed the renationalisation of the European broadcasting sphere in the I950s. Technonationalism paired with protectionist industrial policies therefore constituted a serious setback for ambitions to make television an instrument of transnational or global communication. ${ }^{80}$

\section{The Nation On and Behind the Screens of Television}

The question remains as to why television was perceived as a technology that transcended boundaries on a global level while in fact presenting a very national view of the world. What made television attractive if one looks beyond the rhetoric of advertisements? One important reason for the popularity of television was its promise to function as a mode of political address and communication. Based on the experience with radio broadcasting, all European governments recognised the potential of television to serve as a means of political communication and propaganda. Opening ceremonies and anniversaries of television services, or the yearly radio and television fairs were often used to spread ideas about the role and func-

78 A. Fickers / S. Lommers, «Eventing Europe. Broadcasting and the Mediated Performances of Europe», in: A. Badenoch / A. Fickers (eds.), Materializing Europe. Transnational Infrastructures and the Project of Europe, Basingstoke 2010, 225-25I.

79 M. Akrich, «The De-Scription of Technical Objects», in: W. Bijker / J. Law (eds.), Shaping Technology / Building Society. Studies in Sociotechnical Change, Cambridge 1994, 205-224.
80 A. Fickers, «National Barriers for an Imag(e)ined European Community: The Technopolitical Frames of Post-war Television Development in Europe», in: L. Hojbjerg / H. Sondergaard (eds.), European Film and Media Culture, Copenhagen 2005, I5-36. 


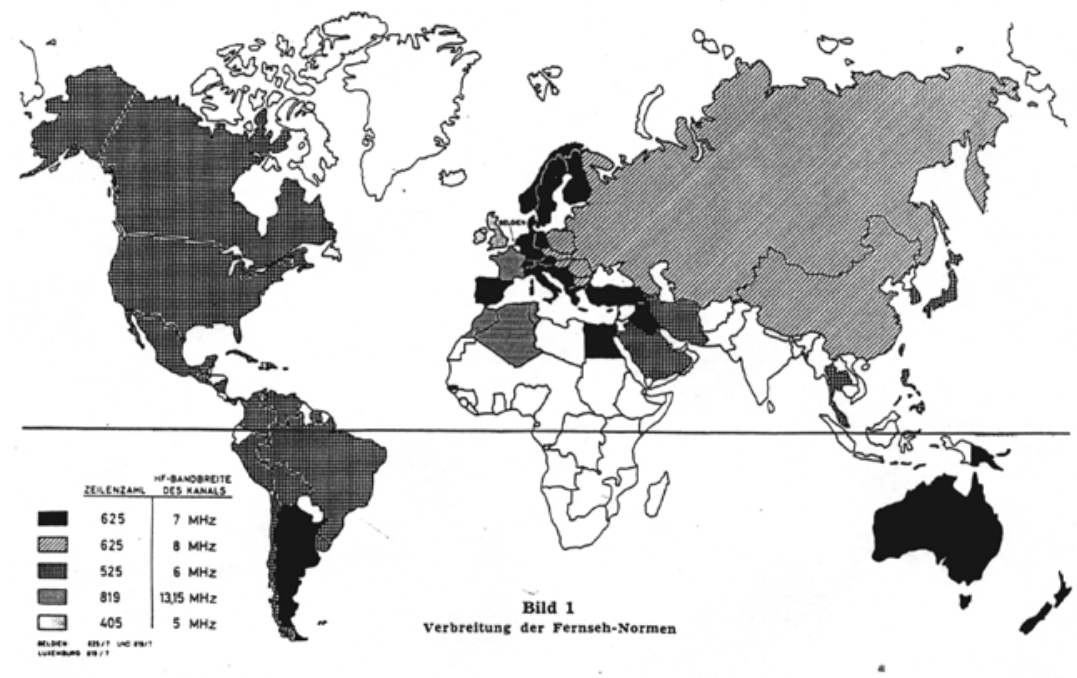

The fragmented European tv landscape of different line-standards in black \& white television.

Source: H. Rindfleisch, Der gegenwärtige Ausbau des Fernsehrundfunks im In- und Ausland, in: Rundfunktechnische Mitteilungen 3 (1959), 220.

tion of television in society. At the Düsseldorf Radio Fair in August I953, the director of the NWDR (the North-West German Broadcasting Organisation), Adolf Grimme, declared that television had to be interpreted as the «electronic agora», the return of direct democracy in the age of mass media. ${ }^{81}$ His French homologue Gabriel Delaunay, director of the RTF (Radio Télédiffusion Française), published an article entitled «La radio-télévision: puissance politique», in which he compared the role of television with the ancient function of the forum. According to Delaunay, the television was now the new electronic forum that had to find its entrance into every home. ${ }^{82}$ French television indeed created a new link between ordinary people and the president; it coined a «national language» and became a catalyst for communion and for the shaping of national sentiments. ${ }^{83}$

This is certainly true for other countries, although the French example is especially interesting as it highlights the tensions between the democratic potential of the medium on the one side and the danger of political instrumentalisation on the other. While television had a rather cumbersome start under the Fourth Republic,

81 M. Elsner / T. Müller / P. Spangenberg, «Zur Entstehung des Dispositivs Fernsehen in der Bundesrepublik Deutschland der fünfziger Jahre», in: K. Hickethier (eds.), Geschichte des Fernsehens in der Bundesrepublik Deutschland, vol. I: Institution, Technik und Programm München I993, 43.
82 E. Cohen, «Télévision, pouvoir et citoyenneté», in: Lévy, La télévision, Paris I999, 26.

83 Ibid., 32. 
the rise of General de Gaulle as president in I958 gave impetus to the development of television in France. De Gaulle himself was acutely aware of the political power of television. During the first two years of his presidency, he delivered no fewer than 32 televisual addresses to the nation and thereby managed to mutate from an already legendary «radio preacher» into a no less impressive «television priest». As he wrote in his memoirs, it was by means of sound and vision that he felt himself closely connected to the nation. ${ }^{84}$ Probably more than any other European politician of his time, de Gaulle recognised the importance of television as a political tool and powerful instrument of social and cultural education. In a private conversation with his Minister of Information, Alain Peyrefitte, de Gaulle confessed: «Who holds television holds the nation.» 85

A fine example of the public celebration of the national importance of radio and television in France under de Gaulle is the inauguration of the Radio Télédiffusion Française's (RTF) new building on I4 December i963. Here, Alain Peyrefitte and de Gaulle addressed the participating honoraries of the French political and cultural elite, and stressed the significance of radio and television as tools for the formation and representation of the grand French nation. Peyrefitte compared the advent of radio and television to the arrival of book printing, and praised the building's modern architecture as a symbol of the «civilisation of sound and image». But this civilisation needed to be closely controlled and observed. ${ }^{86}$ For Peyrefitte - whose critics accused him of being the first censor in the country - radio and television was first of all «une affaire d'État - au sens le plus noble du terme». Like Peyrefitte, de Gaulle aligned television with the other great inventions in communication - from literature, drawing, theatre, print, photography and cinema to radio, and stressed the enormous responsibility of those operating with these instruments of «collective intelligence». For de Gaulle, there was a national responsibility in the use of television as the RTF «breeds our spirit, expresses itself in our language, holds our technology, evokes people and things of our country and fulfills a unique role of national representation». De Gaulle concluded his speech by emphasising the double role of broadcasting as a mirror of the nation and a projection of French identity onto the outside world..$^{87}$

This political interpretation of television as a means of national identity formation was a characteristic pattern in the television discourses of the I950s. Even the

84 «Par le son et par l'image, je suis proche de la nation». C. de Gaulle, Mémoires d'espoir, vol. I: Le renouveau, Paris I970, 30I.

85 Cited in A. Peyrefitte, C'était de Gaulle, vol. 2, Paris 1994,525 .

86 Only a few months before the inauguration of the «Maison de la Radio», July I963, Peyrefitte had installed the «Service de Liaison Interministérielle de l'Information» (SLII), which acted as a severe governmental censorship authority. For details of the organisational structure and functioning of this service, see A. Vassallo, La télévision sous de Gaulle. Le contrôle gouvernmental de l'information (1958-1969), Bruxelles 2005.

87 A recording of the opening ceremony can be seen at the website of the Institut National de l'Audiovisuel (INA). See www.ina.fr (translation by the author). 

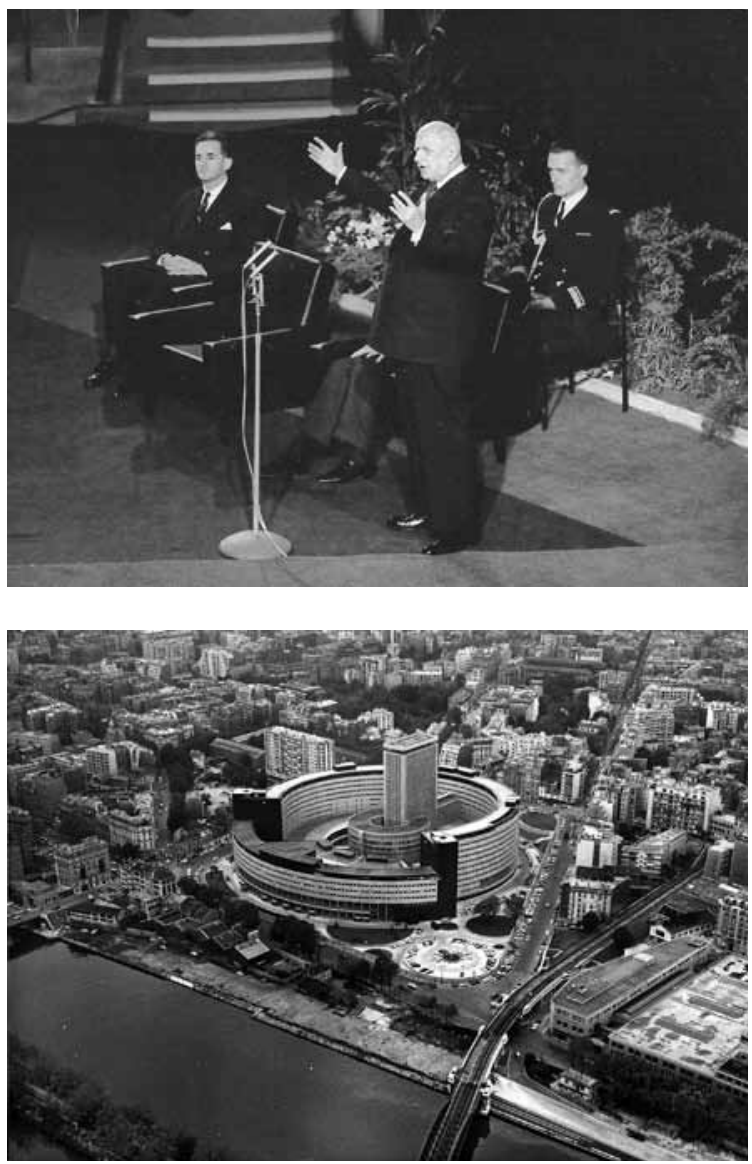

Top: The new radio and television centre of the Radio Télédiffusion Française (RTF), inaugurated by the French President Charles de Gaulle (Bottom) on the 14th of December 1963.

Source: EBU Archives, Geneva.

BBC, usually credited for its «objective» and unagitated style, said its prime mission was to serve the nation - that is, the United Kingdom and the Commonwealth. ${ }^{88}$ When the Television Act of 1954 set out to establish a commercial television service in Britain, the BBC tried to defend its «special position» by referring to the national duty of its service. «In times of stress», it said in a long position paper of January I955, «it is not the regional interests which matter, but the national interest as a whole, and in that respect the great strength of British Broadcasting 
has lain in the standing of the BBC as a national institution, with the power to unite, through broadcasting, the whole people». ${ }^{89}$ In March I958, the director general of the BBC summarized the mission of the BBC as follows: «We must do a national job. [...] We must be serious without being stuffy [...] We must faithfully reflect the greatness of our nation. [...] We shall do our best to make the next twenty-one years in Television adventurous and exciting, and to make our service something of real value to the nation.» ${ }^{90}$

Only the complex interplay between technological infrastructures, ${ }^{91}$ institutional arrangements and cultural ambitions made national coverage and address possible. The creation of umbrella organisations such as the Arbeitsgemeinschaft der öffentlich-rechtlichen Rundfunkanstalten der Bundesrepublik Deutschland (ARD) in Germany in I950 or the Nationale Televisie Stichting (NTS) in the Netherlands in I95I, responsible for the organisation and scheduling of a national television programme, was a crucial prerequisite for the construction of a national audience. In both countries, the collaborative realisation of a national programme by independent broadcast institutions - not least because of the financial limitations of these regional or pillarised organisations and the huge costs of television productions promoted the integration of a fragmented television landscape. In Germany, the ARD started its first common programme in November 1954 and called it «Deutsches Fernsehen» (German Television). After the launch of ZDF (Zweites Deutsches Fernsehen) in I963, the ARD was renamed «Erstes Deutsches Fernsehen»..$^{22}$ As this example shows, the names of the collaborative programmes suggest their national reach and representation. In the Netherlands, this «forced» collaboration between the ideologically competing broadcasting organisations is said to have been an important catalyst in the process of «de-pillarisation» of Dutch society. ${ }^{93}$

Finally, the nationalisation of television was not only shaped by technological infrastructures and institutional arrangements, but also by the televised content itself. During the long I950s, the television screen became the preferred platform for the staging of the nation. Television staples such as the evening news or programmes for children grew into important focal points in people's private lives and became synchronising pulse-generators of social life. Family series for the domestic audience served as public forums for the negotiation of a nation's moral stan-

89 The B.B.C., position paper by the BBC, January I955, 7 pages (here 2), in: National Archives: T 2I9 1422.

90 Script of a talk by Sir Ian Jacob on BBC Television and Commercial Competition, 26.03.1958, in: BBC Written Archives, Caversham, signature T36/3I/2.

91 On the importance of infrastructures for the national integration of a country, see H. Knippen- berg / B. de Pater, De eenwording van Nederland: schaalvergroting en integratie suids 1800 , Nijmegen I9 88 .

92 Hicketier, Geschichte des deutschen Fernsehens, I26-I33.

93 R. Koole, «Hijgende vragen, vlotte babbels. De symbiose van politiek en media», in: J. Bardoel et al. (eds.), Journalistieke Cultuur in Nederland, Amsterdam 2005, IOI-II4. 
dards, and entertainment formats - such as quiz shows or variety shows - allowed for interaction between the viewers at home and the «imagined community» of the general audience. ${ }^{94}$ Last but not least, history programmes on television became one of the most popular vehicles for the (re)invention of the nation. ${ }^{95}$ Both behind and on the screen, television acted as an important propagator of behavioural norms, social standards and political opinions. It is this intimate relationship between television and the project of nation building that seriously complicated or even prevented the development of a transnational televisual space in the long ig50s and beyond.

\section{Conclusion}

The aim of this article was to demonstrate the ambivalent status of television as an emerging medium, a status that was characterised by a constant tension between the potential of television to become a «window to the world» and its use as a tool to serve national interests, and by a tension between its status as a «parasitic medium» and its creative potential as a new form of artistic expression. ${ }^{96}$ Even before people could experience the new medium as a reality of daily life, a technopolitical struggle for line standards had transformed the European television landscape into a highly fragmented space. The hope that television would bring the world into the home by means of transborder reception and transnational programme exchange was - from very early on - frustrated by protectionist industrial strategies. Political ambitions turned the medium into a privileged agent of national socialisation and - at least in some cases - governmental instrumentalisation. When compared to the truly transnational nature of radio broadcasting (at least before the crowding out of middle and short wave radio by the regional implementation of FM radio in the I970s), television - both in its infrastructural, institutional and cultural manifestations - heralded a phase of renationalisation of the broadcasting space. Somewhat provocatively, one could describe this phase - which lasted until the breakthrough of commercial and satellite television in the late I980 - as a global time-out in the history of European broadcasting. ${ }^{97}$

94 There is a huge body of literature on television as a catalyst of national identity formation. For a sophisticated theoretical reflection on the topic, see J. Thompson, The Media and Modernity. A Social Theory of the Media, Cambridge I995.

95 E. Bell / A. Gray (eds.), Television History. Mediating the Past in Postwar Europe, Basingstoke 2010; R. Dillon, History on British Television: Constructing Nation, Nationality and Collective Memory, Manchester 20I0; J. Keilbach, "Geschichte im Fernsehen», in: S. Horn / M. Sauer (eds.), Geschichte und Öffentlichkeit. Orte - Medien - Institutionen, Göttingen 2009, I53-I5O; I. Veyrat-Mas- son, Quand la télévision explore le temps: l'histoire au petit écran, 1953-2000, Paris 2000; S. Reijnders, «Holland on Television: Celebrating the Nation on Television», in: Journal of European Ethnology $36(2006), 45-57$.

96 L. Gorman / D. McLean, Media and Society in the Twentieth Century. A Historical Introduction, Malden 2003 , I27.

97 See J. Chalaby, «The Quiet Invention of a New Medium: Twenty Years of Transnational Television in Europe», in: J. Chalaby (ed.), Transnational Television Worldwide. Towards a New Media Order, London 2005, 43-65. 
With its strong emphasis on the nation, the home and the family, television played an important role during the moral and material recovery of the European continent after the Second World War: it functioned as a catalyst in the process of renationalisation of the post-war broadcasting landscape. Surprisingly, it was the written-off medium of radio that became the central agent of cultural modernisation in both Western and Eastern Europe during the I950s and I960s. In terms of programming (the advent of the format radio), technology (FM) and usage (mobility thanks to the transistor radio), radio successfully reinvented its medial identity and became the vehicle of a new youth and consumer culture. ${ }^{98}$ Together with popular magazines, the disc record and the cinema, radio acted as a powerful mediator in the transfer of political and cultural norms and values not only between America and Western Europe, but also across the Iron Curtain. ${ }^{99}$

To conclude, the intermedial and comparative approach to media history advocated here aims at deconstructing the early dispositif of television, stressing its manifold material interdependencies, structural relationships and cultural or aesthetic affinities with other media. In historicising this process of remediation, two central characteristics became evident: the conservative nature of this evolutionary process in terms of innovation patterns, and the strong nationalistic bent of television as an infrastructure, public service and cultural form. The highly symbolic meaning of television as an apparently «revolutionary» technology and agent of cultural modernisation made television an object used for national staging - from technical standards to political rhetoric. The transnational or global potential of television, although repeatedly used in advertising campaigns by the television industry and as a stable metaphor in early television discourse, was the most prominent victim of this renationalisation of the European broadcasting space. Instead of fulfilling the promise of opening a «window to the world», television - both in its coverage and content - was actually a key player in the «rescue of the nation state» in post-war Europe.

98 R. Chapman, Selling the Sixties. The Pirates and Pop-Music Radio, London I992; A.-M. Sohn, Âge tendre et tête de bois: histoire des jeunes des années 1960, Paris 200I; D. Siegfried, Time is on my side: Konsum und Politik in der westdeutschen Jugendkultur der Goer Jahre, Göttingen 2008; K. Dussel, «Deutsches Radio, deutsche Kultur-Hörfunkprogramme als Indikatoren kulturellen Wandels», in: Archiv für Sozialgeschichte 4I (200I), II9-I44; H. Kleijer / G. Tillekens, «Afgestemd op gezelligheid. De trage aanpassing van de radio aan de jeugdcultuur in de jaren vijftig», in: Luykx / Slot, Een stille revolutie?, I9I-2IO.

99 D. Siegfried, «Underground»: Counter-Culture and the Record Industry in the I960s», in: Führer / Ross , Mass Media, 44-6o; T. Mattelart, Le cheval de troie audiovisuel. Le rideau de fer à l'épreuve des radios et télévisions transfrontières, Grenoble I995; R. Johnson / E. Parta (eds.), Cold War Broadcasting. Impact on the Soviet Union and Eastern Europe. A Collection of Studies and Documents, Budapest 20 IO. 
The Emergence of Television as a Conservative Media Revolution: Historicising a Process of Remediation in the Post-war Western European Mass Media Ensemble

This article claims that the emergence of television in the 1950 s must be interpreted as a conservative media revolution. It aims at revisiting some of the popular narratives about the emergence of television as a revolutionary moment in media history and questions the newness of television in the European mass media ensemble. Focusing on a set of privileged sites of negotiation where the tensions between the conservative and modernising agencies of the medium became most visible or explicit, the article emphasizes the ambiguous and contested nature of television as a new medium. Finally, the author pleas for an integral approach to media history that studies the intermedial relationships and interdependencies between television and other mass media.

\section{Das Aufkommen des Fernsehens als} konservative Medienrevolution: Historisierung eines Prozesses von Remediation im westeuropäischen massenmedialen Ensemble der Nachkriegszeit

Das Aufkommen des Fernsehens in den 1950er Jahren muss - so die These dieses Artikels - als konservative Medienrevolution interpretiert werden. Dabei sollen einige der verbreiteten Erzählungen wie das Aufkommen des Fernsehens als revolutionäres Ereignis der Mediengeschichte bzw. die Neuartigkeit des Fernsehens im europäischen massenmedialen Ensemble hinterfragt und überdacht werden. Indem sich der Artikel auf eine Reihe von Verhandlungsorten konzentriert, anhand der sich die Spannungen zwischen konservativen und modernisierenden Kräften des Mediums besonders gut erkennen lassen, betont er den ambivalenten und umstrittenen Charakter des Fernsehens als neues Medium. Zum Schluss entwirft der Autor einen integrierenden mediengeschichtlichen Ansatz, der sowohl die intermedialen Beziehungen als auch die Wechselwirkungen zwischen dem Fernsehen und anderen Massenmedien berücksichtigt.

\section{L'émergence de la télévision en tant que}

révolution médiatique

conservatrice: L'historicisation d'un processus

de remediation dans l'ensemble ouest-européen des médias de masse de l'après-guerre

L'émergence de la télévision dans les années 1950 doit, telle est l'hypothèse de l'article, être interprétée en tant que révolution médiatique conservatrice. L'objectif est de revisiter les récits populaires faisant de l'émergence de la télévision un instant révolutionnaire de l'histoire des médias tout en s'interrogeant sur la nouveauté de la télévision dans l'ensemble des médias de masse en Europe. En se concentrant sur une série de lieux de négociations rendant les tensions entre les 
forces conservatrices et modernisatrices du médium plus visibles ou plus expliABSTRACTS cites, l'article souligne la nature ambigüe et contestée de la télévision en tant que nouveau médium. Enfin, l'auteur plaide pour une approche intégrée de l'histoire des médias qui étudie non seulement les relations entre les médias, mais aussi les interdépendances entre la télévision et les autres médias de masse.

Anschrift Autor 